\begin{tabular}{lll}
\hline NOMOR XXI (1) & April 2015 & Halaman 34-42 \\
\hline
\end{tabular}

\title{
PERAN PARTAI POLITIK DALAM PENDIDIKAN POLITIK GENERASI MUDA DAN IMPLIKASINYA TERHADAP KETAHANAN POLITIK WILAYAH (Studi Di DPD II Partai Golongan Karya Kota Malang Jawa Timur Tahun 2009 - 2014)
}

\author{
Yulianto Dwi Saputro \\ Universitas Gadjah Mada, Program Studi Ketahanan Nasional \\ Email: antokindonesia8@gmail.com
}

\begin{abstract}
A political party was an important element in democratic countries. One of the functions of the establishment of political parties as political institutions that were responsible for providing political education to the cadres of political parties as well as to the wider community. In a democratic political system political party of choice as a means to realized the ideals of the nation and the state. Political education was an effort to realized the Indonesian democracy healthy and quality. This study aimed to discussed the role of political parties in the political education of the younger generation and its implications for political resilience in the study area with the second DPD Golkar Party Malang East Java.

The method in this research was descriptive qualitative, which described the complex social phenomena occured in society. The research process was done by selecting informants who were deemed eligible research with purposive sampling method. In this case the Golkar Party officials Malang. The technique of research by conducting in-depth interviews, observation, literature study and documentation. Then analyzed with three grooves activities that occurred simultaneously, namely data reduction, data presentation, drawing conclusions or verification

The results showed that the role of political parties in providing the cadres and political education to the public remains low. Methods and materials for political education conducted by the political parties were still very conceptual and less applicable. Evaluation methods in the provision of political education was not operating effectively, so that the role of political parties in providing awareness to the community about the rights and obligations as citizens to be low. oreover, the resulting low level of quality cadres of political parties in encouraging the improvement of people's lives. Implications of the role of political parties in the political education of the younger generation of political resilience of region adversely affected the political participation of society and the low level of public participation in public policy-making and oversight.
\end{abstract}

Keywords: Political Parties, Political Education, Youth Generation, Political Resilience of Region.

\begin{abstract}
ABSTRAK
Partai politik merupakan elemen penting dalam negara demokrasi. Salah satu fungsi dari dibentuknya partai politik sebagai institusi politik yang bertanggung jawab dalam memberikan pendidikan politik kepada kader partai politik maupun kepada masyarakat luas. Dalam sistem politik yang demokrasi partai politik menjadi pilihan sebagai alat untuk mewujudkan cita-cita bangsa dan negara. Pendidikan politik merupakan usaha untuk mewujudkan demokrasi Indonesia yang sehat dan berkualitas. Penelitian ini bertujuan membahas tentang peran partai politik dalam pendidikan politik generasi muda dan implikasinya terhadap ketahanan politik wilayah dengan studi pada DPD II Partai Golongan Karya Kota Malang Jawa Timur.
\end{abstract}


Yulianto Dwi Saputro -- Peran Partai Politik Dalam Pendidikan Politik Generasi Muda Dan Implikasinya Terhadap Ketahanan Politik Wilayah (Studi Di DPD II Partai Golongan Karya Kota Malang

Jawa Timur Tahun 2009-2014)

Metode dalam penelitian ini bersifat deskriptif kulitatif, yang menggambarkan fenomena sosial yang komplek terjadi di masyarakat. Proses penelitian dilakukan dengan pemilihan informan yang dianggap memenuhi kriteria penelitian dengan metode purposive sampling. Dalam hal ini adalah pengurus Partai Golkar Kota Malang. Adapun teknik penelitian dengan melakukan wawancara mendalam, observasi, studi kepustakaan dan dokumentasi. Selanjutnya dianalisis dengan tiga alur kegiatan yang terjadi secara bersamaan, yaitu reduksi data, penyajian data, penarikan kesimpulan atau verifikasi.

Hasil penelitian menunjukan bahwa peran partai politik dalam memberikan pendidikan politik kepada kader maupun kepada masyarakat masih rendah. Metode serta materi pendidikan politik yang dilakukan oleh partai politik masih sangat konseptual dan kurang aplikatif. Metode evaluasi dalam pemberian pendidikan politik tidak berjalan dengan efektif, sehingga peran partai politik dalam memberikan penyadaran kepada masyarakat tentang hak dan kewajibannya sebagai warga negara menjadi rendah. Selain itu, berakibat rendahnya tingkat kualitas kader partai politik dalam mendorong perbaikan kehidupan masyarakat. Implikasi peran partai politik dalam pendidikan politik generasi muda terhadap ketahanan politik wilayah berdampak pada rendahnya partisipasi politik masyarakat dan rendahnya tingkat peran serta masyarakat dalam pembuatan serta pengawasan kebijakan publik.

\section{Kata Kunci: Partai Politik, Pendidikan Politik, Generasi Muda, Ketahanan Politik Wilayah.}

\section{PENGANTAR}

Partai politik merupakan sebuah institusi yang mutlak diperlukan dalam dunia demokrasi, apabila sudah memilih sistem demokrasi dalam mengatur kehidupan berbangsa dan bernegara maka salah satu instrument penting dalam demokrasi adalah institusi partai politik. Tanpa partai politik maka demokrasi tidak bisa bekerja dengan baik. Oleh karena itu, hidupnya demokrasi sangat tergantung pada hidup dan berkembangnya partai politik. Partai politik merupakan salah satu pilar dalam demokrasi. Dengan adanya partai politik, aspirasi dan keinginan dari rakyat dapat tersalurkan dengan baik (Budiardjo,1998).

Salah satu fungsi partai politik adalah bertanggung jawab terhadap pendidikan politik bagi kader partai tersebut maupun bagi masyarakat sekitar. Di sisi lain, peran pemuda sebagai lokomotif perubahan dan demokrasi itu sendiri sangat tinggi, yang menjadi pertanyaan adalah bagaimana peran partai politik khususnya Partai Golongan Karya Kota Malang dalam peningkatan kualitas pendidikan politik warga negara terutama di kalangan generasi muda Kota Malang yang pada akhirnya akan berpengaruh terhadap ketahanan politik Kota Malang. Oleh karena itu tujuan penelitian ini adalah untuk 1) Untuk mengetahui peran Partai Golongan Karya dalam pendidikan politik generasi muda di wilayah Kota Malang. 2) Untuk mengetahui implikasi dari peran Partai Golongan Karya dalam pendidikan politik bagi generasi muda terhadap ketahanan politik wilayah Kota Malang.

Dalam penelitian ini jenis penelitiannya adalah deskriptif dengan menggunakan metode kualitatif. Sebagaimana yang dikemukakan oleh Kaelan (2012) bahwa penelitian deskriptif bertujuan untuk menggambarkan suatu fenomena, karakteristik, situasi atau kejadian pada suatu daerah tertentu secara sistematis, faktual dan akurat sebagaimana mestinya. Penelitian ini dilakukan di wilayah Kota Malang Provinsi Jawa Timur dengan fokus penelitian pada DPD II Partai Golongan Karya (Golkar) Kota Malang.

Untuk memperoleh data dalam penelitian ini, peneliti menggunakan beberapa data, yaitu:

Pertama data primer, yaitu data langsung yang diperoleh dari informan atau narasumber. 
Kedua data sekunder, yaitu data yang diperoleh tidak secara langsung melainkan hasil olahan dari data lain seperti tabel, laporan - laporan, dan dokumentasi, serta literaturliteratur buku yang masih berhubungan dengan proses penelitian. Adapun data dalam penelitian ini diperoleh dengan 4 teknik. Pertama, teknik wawancara mendalam (indepth interview). Kedua, observasi. Ketiga, studi kepustakaan dengan mengumpulkan dan mempelajari literatur atau buku-buka yang berhubungan dengan fokus penelitian ini. Keempat, dokumentasi.

Dalam penelitian ini menggunakan teknik analisis data secara deskriptif analisis. Bersifat deskriptif analisis karena akan menggambarkan dan menerangkan permasalahan pelaksanaan yang berkaitan dengan peran partai Golongan Karya Kota Malang dalam pendidikan politik bagi generasi muda Kota Malang, kemudian dianalisis secara cermat bagaimana implikasinya terhadap ketahanan politik wilayah Kota Malang. Analisa data yang dilakukan adalah menguraikan atau menggambarkan tentang suatu gejala dalam penelitian sehingga dapat menjawab permasalahan penelitian dengan sejelas-jelasnya (Singarimbun dan Effendi, 1989; Kaelan, 2012).

Sejauh penelusuran peneliti, terdapat 3 penelitian yang membahas tentang peran partai politik dalam kehidupan demokrasi di Indonesia. Tiga penelitian tersebut adalah; 1. "Peranan partai poltik dalam merealisasikan prinsip - prinsip negara hukum yang demokratis pada pemilihan kepala daerah secara langsung", oleh Ledi Lagu; 2. "Peran Partai Politik Dalam Peningkatan Demokratisasi Masyarkat Sipil (Civil Society) Dan Implikasinya Terhadap Ketahanan Politik, (studi pustaka)", oleh Doni Irza. 3."Partisipasi Warga Nahdliyin Dalam Partai Politik Dan Implikasinya Bagi
Ketahanan Bidang Politik di Kabupaten Semarang Propinsi Jawa Tengah," oleh Achsin. Dari tinjauan tiga penelitian di atas, dapat ditemukan kesamaan penemuan bahwa pendidikan politik adalah salah satu elemen penting dalam pembangunan demokrasi.

\section{PEMBAHASAN}

\section{Gambaran Umum Kota Malang Provinai Jawa Timur \\ Kondisi Geografi Dan Demografi}

Badan Pusat Statistik (BPS) Kota Malang menyebutkan bahwa Kota Malang terletak di ketinggian 440 - 667 di atas permukaan air laut merupakan salah satu daerah otonom dan merupakan kota terbesar kedua di Provinsi Jawa Timur. Secara astronomis Kota Malang terletak di 112,06" - 112,07" Bujur Timur dan 7,06" 8,02" Lintang Selatan. Kota Malang terdiri dari 5 Kecamatan yaitu Kedungkandang, Klojen, Blimbing, Lowokwaru, dan Sukun serta 57 kelurahan. (BPS kota Malang, 2013)

\section{Kondisi Politik Dan Pemerintahan}

Di Kota Malang, pemilu pasca reformasi selalu dimenangkan oleh PDIP, kecuali pemilu tahun 2009, PDIP berada di posisi kedua setelah Partai Demokrat. Pada Pemilu tahun 2014 juga dimenangkan oleh PDIP dengan perolehan suara sebanyak 92.217 suara dengan perolehan 11 kursi (http://kpud-malangkota.go.id/).

Tepat pada bulan Mei 2013 Kota Malang mengadakan Pemilihan Kepala Daerah atau Pemilihan Walikota dan Wakil Walikota. Dalam Pilkada Kota Malang Periode 2013 - 2018 tersebut diikuti oleh 6 pasang calon yaitu: 1) Dwi Cahyono - Nuruddin (DWI UDDIN) mewakili calon independen; 2) Sri Rahayu - Priyatmoko Oetomo (SR-MK) diusung oleh PDIP dan PDS; 3) Heri Pudji 
Yulianto Dwi Saputro -- Peran Partai Politik Dalam Pendidikan Politik Generasi Muda Dan Implikasinya Terhadap Ketahanan Politik Wilayah (Studi Di DPD II Partai Golongan Karya Kota Malang Jawa Timur Tahun 2009-2014)

Utami - Sofyan Edi Jarwoko (DADI) diusung oleh Partai Golkar, PAN dan 14 partai non parlemen; 4) Achmad Mujais - Yunar Mulya (RAJA) mewakili calon independen; 5) Agus Dono - Arif HS (DOA) diusung oleh Partai Demokrat, PKS, Hanura dan PKPB; 6) Mohammad Anton - Sutiaji (AJI) diusung oleh PKB dan Gerindra.

Pada akhirnya, pemilihan walikota dan wakil walikota Malang yang dilaksanakan pada tanggal 23 Mei 2013 berhasil mengantarkan pemimpin baru di Kota Malang, yaitu Mohammad Anton dan Sutiaji (AJI). Mereka memenangi pemilihan walikota Malang tersebut dengan satu putaran dengan memperoleh total suara sebanyak 179.675.(KPU Kota Malang, 2013)

\section{Kondisi Ekonomi}

Salah satu cara untuk mengetahui kinerja dari suatu masalah antara lain dengan melihat seberapa besar nilai tambah yang dihasilkan oleh faktor - faktor produksi yang ada di suatu wilayah. Besaran nilai tambah yang dihasilkan oleh faktor - faktor produksi tersebut umumnya disebut dengan Produk Domestik Regional Bruto (PDRB). PDRB ini dikelompokkan menjadi sektor, yaitu sektor perdagangan, hotel dan restoran, sektor bangunan, sektor listrik, gas dan air bersih, sektor pengangkutan dan komunikasi sektor keuangan, sektor jasa-jasa, sektor pertanian, sektor industri pengolahan serta sektor pertambangan dan penggalian.

Perhitungan dilakukan dengan dua cara yaitu PDRB berdasarkan harga tahun berjalan/ berlaku dan atas harga dasar pada tahun dasar (konstan) tertentu. Tahun yang digunakan sebagai dasar penghitungan adalah 2013. Dari data tahun 2013, kontribusi yang cukup signifikan membangun perekonomian Kota Malang yaitu sektor industri pengolahan $(35,84 \%)$, kemudian diikuti oleh sektor perdagangan, hotel dan restoran $(32,22 \%)$, sektor jasa-jasa $(11,64 \%)$, sektor keuangan $(8,33 \%)$. Sedangkan sektor lainnya $(11,97 \%)$ meliputi sektor pengangkutan dan komunikasi, pertambangan, pertanian, bangunan, listrik, dan gas rata-rata 2-3\% (BPS Kota Malang, 2013).

\section{Kondisi Sosial Budaya}

Kondisi sosial budaya dan kehidupan beragama merupakan aspek penting dalam pembangunan manusia yang diejawantahkan dalam wujud penigkatan kesejahteraan dan kualitas hidup masyarakat. Kota Malang tidak akan pernah terlepas dengan kata Arema dan Aremania. Arema merupakan penunjuk sebuah komunitas asal Malang. Arema adalah akronim dari Arek Malang. Arema menjadi semacam "subkultur" dengan identitas, simbol dan karakter bagi masyarakat Malang. Diyakini, Arek Malang membangun reputasi dan eksistensinya di antaranya melalui musik rock dan olahraga. Selain tinju, sepak bola adalah olahraga yang menjadi jalan bagi arek malang menunjukkan reputasinya.

Di Kota Malang sendiri dalam rangka peningkatan nilai - nilai keagamaan, terdapat agenda pengajian rutin setiap hari kamis yang terkenal dengan istilah Riyadlul Jannah. Pengajian ini berlangsung dengan bergantiganti tempat berkeliling ke seluruh penjuru Kota Malang.

\section{Peran Partai Golkar Dalam Pendidikan Politik Generasi Muda Kota Malang Partai Golkar Kota Malang}

Sejarah berdirinya DPD II Partai Golkar Kota Malang tidak terlepas dari sejarah berdirinya Partai Golkar itu sendiri. Sejarah 
Partai Golkar bermula pada tahun 1964 dengan berdirinya Sekber Golkar di masa akhir pemerintahan Presiden Soekarno. Sementara itu di Kota Malang Sekber Partai Golkar terbentuk dua tahun kemudian yaitu pada tahun 1968 dengan Dollah sebagai ketua umumnya. Bapak Dollah memimpin Sekber Golkar Kota Malang hingga tahun 1968 1971. Sekber Golkar Kota Malang yang sudah berganti nama menjadi Partai Golkar Kota Malang pada tahun yang sama mengadakan Musyawarah Daerah (Musda) I dengan Drs. Muhaji Wijaya terpilih sebagai ketua umum. Beliau menjabat ketua umum Partai Golkar Kota Malang hingga tahun 1977.

Tabel 1.

Daftar Nama Ketua Umum Partai Golkar Kota Malang

\begin{tabular}{|c|l|c|}
\hline NO & NAMA & PERIODE \\
\hline 1 & Bpk. Dollah & $\begin{array}{c}1968-1971 \\
\text { (Sekber Golkar) }\end{array}$ \\
\hline 2 & Drs. Muhaji Wijaya & $1971-1977$ \\
\hline 3 & Slamet Harjo Oetomo & $1977-1984$ \\
\hline 4 & Kol. Sumarto & $1984-1989$ \\
\hline 5 & Kol. Paiman & $1989-1997$ \\
\hline 6 & Drs. Bambang Priyo Oetomo, BSc & $1997-2004$ \\
\hline 7 & Drs. Aries Pudjangkoro, MM & $2004-2009$ \\
\hline 8 & Ir. Sofyan Edi Jarwoko & $2009-2015$ \\
\hline
\end{tabular}

Sumber: Kesekretariatan DPD II Partai Golkar Kota Malang

Visi dan Misi Partai Golkar Kota Malang adalah (1) Partai Golkar Kota Malang berjuang demi terwujudnya Kota Malang baru yang maju, modern, bersatu, damai, adil dan makmur dengan masyarakat yang beriman dan bertaqwa, berahlak baik, menjunjung tinggi hak asasi manusia, cinta tanah air, demokratis, dan adil dalam tatanan masyarakat Malang yang mandiri, terbuka, egaliter, berkesadaran hukum dan lingkungan, menguasai ilmu pengetahuan dan teknologi, memiliki etos kerja dan semangat kekaryaan, serta disiplin yang tinggi. (2)
Mewujudkan kehidupan politik Kota Malang yang demokratis melalui pelaksanaan agendaagenda reformasi politik yang diarahkan untuk melakukan serangkaian koreksi terencana, melembaga dan berkesinambungan terhadap seluruh bidang kehidupan masyarakat Kota Malang. (3) Menegakkan, mengamalkan, dan mempertahankan Pancasila sebagai dasar Negara dan idiologi bangsa demi untuk memperkokoh Negara Kesatuan Republik Indonesia; dan mewujudkan cita-cita Proklamasi melalui pelaksanaan pembangunan nasional di segala bidang. (4) Mewujudkan masyarakat Kota Malang yang demokratis, menegakkan supremasi hukum, mewujudkan kesejahteraan rakyat, dan hak-hak asasi manusia. (5) Mempertegas komitmen untuk menyerap, memadukan, mengartikulasikan, dan memperjuangkan aspirasi warga Kota Malang sehingga menjadi kebijakan politik yang bersifat publik. (6) Melakukan rekruitmen kader-kader yang berkualitas melalui sistem prestasi (merit system) untuk dapat dipilih oleh rakyat menduduki posisi-posisi politik atau jabatanjabatan publik. Dengan posisi atau jabatan politik ini maka para kader dapat mengontrol atau mempengaruhi jalannya pemerintahan Kota Malang untuk diabdikan sepenuhnya bagi kepentingan dan kesejahteraan warga Kota Malang.

Struktur kepengurusan harus dan wajib mengikuti aturan partai yang tertuang dalam AD/ART Partai Golkar. Dalam AD/ART Pasrtai Golkar pasal 8 menerangkan bahwa kepengurusan Dewan Pimpinan Daerah sekurang-kurangnya harus memiliki 3 unsur pokok kepengurusan yaitu : Ketua, Sekretaris dan Bendahara. Tiga unsur kepengurusan tersebut menjadi poin minimal ketika suatu 
Yulianto Dwi Saputro -- Peran Partai Politik Dalam Pendidikan Politik Generasi Muda Dan Implikasinya Terhadap Ketahanan Politik Wilayah (Studi Di DPD II Partai Golongan Karya Kota Malang Jawa Timur Tahun 2009-2014)

kepengurusan dewan pimpinan daerah Partai Golkar dianggap sah dan legal.

Kepengurusan DPD II Partai Golkar Kota Malang dengan berkiblat pada AD/ ART Partai Golkar Pasal 8 tersebut, memiliki susunan kepengurusan yang terdiri dari satu orang ketua, dan 10 orang wakil ketua bidang, satu orang sekretaris umum dan 10 orang wakil sekretaris, satu orang bendahara serta 5 orang wakil bendahara.

\section{Peran Partai Golkar Kota Malang Dalam Pendidikan Politik Generasi Muda}

Partai Golkar Kota Malang dalam prosesnya menyelenggarakan pendidikan politik melalui dua grand design materi kependidikan, yaitu melalui: (1) Proses ideologisasi kepartaian, dan (2) pelaksanaan proker (program kerja) partai. Partai Golkar sebagai partai yang berideologi nasionalis, menempatkan Pancasila sebagai ideologi partai. Hal ini disebutkan pada AD/ART Partai Golongan Karya BAB III Pasal 1 bahwa asas Partai adalah Pancasila. Dalam pasal tersebut menjelaskan dengan tegas bahwa ideologi Partai Golkar adalah Pancasila. Pancasila menjadi satu - satunya ideologi yang dianut oleh Partai Golkar

Dalam proses ideologisasi kepartaian tersebut, terdapat beberapa cara atau metode yang dilakukan oleh Partai Golkar Kota Malang, yaitu (1) mewajibkan kader untuk menghafal dan memahami Ikrar Panca Bhakti, (2) mendekorasi kesekretariatan Partai Golkar Kota Malang dengan bendera dan lambang lambang negara.

Pelaksanaan program kerja - program kerja Partai Golkar Kota Malang dalam usahanya menjalankan pendidikan politik, memfokuskan pada 3 bidang kerja saja yaitu: (1) Bidang Organisasi, Keanggotaan \& Kaderisasi.(2) Bidang Pendidikan dan Pelatihan. (3) Bidang Pemuda, Olahraga dan Seni Budaya. Hal ini dikarenakan pada 3 bidang tersebut merupakan representasi pengimplementasian dari pendidikan politik yang dilakukan oleh Partai Golkar Kota Malang terhadap internal kader maupun terhadap masyarakat.

Metode pendidikan politik yang dilakukan oleh Partai Golkar Kota Malang terbagi menjadi dua yaitu: Pertama, pendidikan politik secara formal yaitu bentuk pendidikan politik yang dilakukan oleh partai secara formal dan mempunyai sifat legal dalam konstitusi partai. Pendidikan politik secara formal ini dapat dilihat dengan membedah program - program kerja Partai Golkar Kota Malang dalam fungsinya sebagai sarana pendidikan politik yang sudah ditetapkan dan disahkan oleh mekanisme internal partai. Kedua, metode pendidikan politik secara informal dapat diartikan dengan proses pendidikan politik yang dilakukan dengan konsep tidak formal melalui diskusi pada mimbar bebas, warung kopi, maupun dalam bentuk jagongan. Proses pendidikan politik dengan memberi contoh keteladanan pemimpin politik bagaimana cara berpolitik yang sehat, berkompetisi yang baik, dan menghormati peraturan yang telah disepakati bersama merupakan salah satu contoh model pendidikan politik secara informal (Firmansyah, 2011: 79)

\section{Kendala-Kendala Pendidikan Politik Partai Golkar Kota Malang}

Partai Golkar Kota Malang dalam fungsinya sebagai sarana pendidikan politik mempunyai kendala dalam setiap pelaksanaan program - program pendidikan politik tersebut. 
Kendala tersebut terjadi sebagai bentuk prosesi alamiah dalam setiap perjalanan organisasi yang sedang berproses menuju ketercapaian tujuannya. Kendala - kendala tersebut adalah: (1) pendanaan, (2) latar belakang pendidikan kader, (3) materi dan perencanaan pendidikan kader kurang optimal, dan yang terakhir (4) Lemahnya metode evaluasi kaderisasi.

\section{Partisipasi Politik Generasi Muda Partai Golkar Kota Malang}

Partisipasi politik merupakan bentuk penyaluran keikutsertaan masyarakat dalam kehidupan berpolitik berbangsa dan bernegara. Partisipasi politik adalah kegiatan seseorang atau kelompok orang untuk ikut serta secara aktif dalam kehidupan politik, yaitu dengan jalan memilih pemimpin negara dan secara langsung atau tidak langsung, mempengaruhi kebijakan pemerintah.(Budiardjo,1998). Bentuk partisipasi tersebut adalah dengan pemberian materi yang disampaikan dalam pendidikan politik Partai Golkar Kota Malang adalah berisi tentang penyadaran masyarakat terutama generasi muda tentang pentingnya berperan aktif dalam pemilihan umum. Pentingnya ikut nyoblos atau tidak golput dalam pemilu sangat diperhatikan oleh setiap pengurus Partai Golkar Kota Malang di setiap agenda pendidikan politik oleh pengurus partai.

Selain itu, Pada pilwakot Kota Malang 2013 Partai Golkar Kota Malang ikut berpartisipasi aktif dengan mengirimkan kadernya sebagai calon wakil walikota saudara Sofyan Edi Jarwoko, beliau berpasangan dengan $\mathrm{Hj}$. Heri Pudji Astuti. Dalam pemilukada Kota Malang 2013 tersebut pasangan ini menempati urutan ketiga dengan perolehan sebanyak 68.971 suara atau 18,4 persen (http://kpud-malangkota. go.id/). Sedangkan pada Pemilu 2014, Partai Golkar Kota Malang telah meloloskan 5 orang kadernya sebagai anggota DPRD Kota Malang yaitu : (1) Sukarno, (2) Choeroel Anwar SP, (3) Rahayu Sugiarti S.Sos, (4) Drs. Ribut Hariyanto MM, (5) Ir. Bambang Sumarto. Dari semua peserta pemilu 2014 Partai Golkar Kota Malang untuk rekapitulasi perolehan suara DPR RI berada pada urutan no 3 dengan perolehan suara sebanyak 32. 699. Sementara untuk DPRD Provinsi Jawa Timur Partai Golkar di Kota Malang mendapatkan 30.871 suara (http://kpud-malangkota.go.id/).

Dalam hal penyaluran aspirasi masyarakat kinerja Partai Golkar Kota Malang cenderung kurang maksimal, hal ini dikarenakan banyak kader Partai Golkar yang menjadikan partai hanya sekedar kendaraan politik semata untuk memperoleh jabatan-jabatan publik. Konsepsi partai politik sebagai penyalur aspirasi masyarakat tidak lagi menjadi prioritas utama dalam perjuangan para kader partai politik. Pun demikian di Partai Golkar Kota Malang, minimnya produktifitas kinerja dari kader kader internal partai sangat berkorelasi dengan minimnya peran serta Partai Golkar Kota Malang sebagai penyalur aspirasi masyarakat Kota Malang.

\section{Implikasi Peran Partai Golkar Dalam Pendidikan Politik Generasi Muda Terhadap Ketahanan Politik Wilayah Kriteria Ketahanan Politik Wilayah}

Ketahanan politik adalah sebagai kondisi dinamik kehidupan politik bangsa yang berisi keuletan, ketangguhan yang mengandung kemampuan mengembangkan kekuatan nasional dalam menghadapi tantangan, hambatan serta gangguan yang berasal dari luar dan dari dalam secara langsung maupun 
Yulianto Dwi Saputro -- Peran Partai Politik Dalam Pendidikan Politik Generasi Muda Dan Implikasinya Terhadap Ketahanan Politik Wilayah (Studi Di DPD II Partai Golongan Karya Kota Malang

Jawa Timur Tahun 2009-2014)

tidak langsung untuk menjamin kehidupan politik bangsa dan negara Republik Indonesia berdasarkan Pancasila dan UUD 1945.

Berdasarkan konsep ketahanan politik tersebut dapat diartikan bahwa ketahanan politik wilayah merupakan ketahanan politik pada suatu wilayah atau daerah yang berisi keuletan dan ketangguhan yang mengandung kemampuan untuk mengembangkan kekuatan wilayah dalam menghadapi tantangan, ancaman, hambatan serta gangguan yang datang dari luar wilayah maupun dari dalam wilayah secara langsung maupun tidak langsung untuk menjamin kehidupan berpolitik di wilayah tersebut. Dalam hal ini adalah ketahanan politik wilayah Kota Malang.

\section{Implikasi Terhadap Ketahanan Politik Wilayah Kota Malang}

Wawasan politik masyarakat menggambarkan tingkat kesadaran politik anggota masyarakat. Wawasan politik ini mempengaruhi sejauh mana masyarakatikut serta dalam aktifitas politik, dan juga mempengaruhi perilaku aktor - aktor yang terlibat dalam prosesi politik.(Firmasnsyah;2011). Dengan melihat realitas usaha dari Partai Golkar Kota Malang dalam menjalankan tugas dan fungsinya sebagai sarana pendidikan politik serta implikasinya terhadap ketahanan politik Kota Malang maka dapat dikatakan bahwa peran Partai Golkar Kota Malang memiliki implkasi yang cukup positif dalam membangun ketahanan politik wilayah Kota Malang yang tangguh dan ulet meskipun tingkat pengaruhnya masih sangat rendah.

\section{SIMPULAN}

Kehidupan berpolitik bangsa Indonesia yang diwakili oleh tata kelola partai politik masih jauh dari keadaan yang ideal. Partai politik yang menjadi salah satu pilar utama kehidupan berdemokrasi dan berpolitik masih harus terus berproses dalam menjalankan amanat sebagai penyalur aspirasi masyarakat. Partai politik belum menjadikan pendidikan politik sebagai sorotan utama. Pendidikan politik seakan tenggelam diantara hiruk pikuk perebutan kekuasaan. Pendidikan politik bagi Partai Golkar Kota Malang menjadi prioritas utama, akan tetapi dalam pelaksanaanya pendidikan politik yang diberikan secara eksternal kepada masyarakat luas khususnya generasi muda masih bersifat pencitraan partai belaka. Hal-hal yang wajib dan substansial seperti konsepsi tentang demokrasi dan pemahaman tentang hak dan kewajiban sebagai warga negara serta pemahaman tentang ideologi Pancasila dan UUD 1945 yang seharusnya diberikan kepada masyarakat kurang diperhatikan secara optimal Ketidak optimalan pendidikan politik kepada internal kader Partai Golkar Kota Malang itu dapat terlihat dari program-program kerja partai yang masih banyak yang bersifat umum. Program kerja Partai Golkar tidak menjelaskan secara mendetail tentang filosofi pendidikan politik yaitu pola pikir kritis dan mandiri.

Ada 4 saran yang peneliti ajukan dalam penelitian ini, yaitu: (1) Manajemen pengelolaan pendanaan partai politik perlu ditingkatkan. (2) Pola rekrutmen kader pada partai politik perlu ditingkatkan. (3) Perlu adanya model/sistem baru yang lebih komunikatif dan efektif bagi partai politik dalam memberikan pendidikan politik bagi masyarakat luas khususnya generasi muda. (4) Intensitas serta metode evaluasi pendidikan politik yang diberikan kepada masyarakat masih sangat kurang, sehingga perlu peningkatan intensitas dan produktifitas 
program dikerja bagi partai politik untuk melakukan pendidikan politik kepada warga masyarakat dan generasi muda.

\section{DAFTAR PUSTAKA}

Budiardjo, Miriam. 1998. Partisipasi dan partai politik: sebuah bunga rampai. Yogjakarta: Yayasan Obor Indonesia

BPS Kota Malang, 2013, Kota Malang Dalam Angka 2013, Malang : BPS Kota Malang

Firmanzah. 2011. Mengelola Partai politik; Komunikasi dan Positionong Ideologi Politik di Era Demokrasi. Jakarta:
Yayasan Obor Indonesia .

Kaelan, H., 2012, Metode Penelitian Kualitatif Interdisipliner, Yogyakarta: Paradigma KPU Kota Malang, 2013, Rekapitulasi Akhir Pemilihan Walikota Dan Wakil Walikota Malang Tahun 2013, Malang: KPU Kota Malang

Singarimbun, M. Sofian, M. 1989. Metode

Penelitian Survei. Jakarta: LP3S

\section{Internet:}

http://Kpud-malang kota.go.id 